\title{
IMPROVED OF THE ENVIRONMENT CARE ATTITUDE ON SCIENCE LEARNING BY APPLYINGTHE SCIENCE ENVIRONMENT TECHNOLOGY AND SOCIETY (SETS) MODEL
}

\author{
Husnul Khotimah, Hadi Mulyono, Anesa Surya \\ Universitas Sebelas Maret \\ husnulkhotimah782@gmail.com
}

Article History

accepted 09/07/2018

approved 01/08/2018

published 17/09/2018

\section{Keywords}

Environmental care attitude, Science Environment Technology and Society (SETS)

\begin{abstract}
Environmental care attitude is one of important character to be grown from an early age. The attitude of environmental care of grade fifth student of SDN 1 Mendak is still low. The purpose of the research is to improve of the environment care attitude through models of science environment technology and society (SETS) in the fifth grade students of State Elementary School 1 Mendak in academic year 2017/2018. This research forms is Classroom Action Research and it was conducted in two cycles. Each cycle consists of four step, there are planning, acting, observing, and reflecting. The subject of this research is the fifth grade students of State Elementary School 1 Mendak. Technique of the data collecting used are questionnaire, observation, interview, and documentation. The data validity used triangulation of resources and triangulation of technique. Technique of the data analysis used is interactive analysis. Result of this research indicate that environmental care attitude of grade 5 student of SDN 1 Mendak from preaction until cycle II meeting 2 has increased by $83,3 \%$. The conclusion of this research indicate that through models of science environment technology and society (SETS) can improve of the environment care attitude in the fifth grade students of State Elementary School 1 Mendak in academic year 2017/2018.
\end{abstract}

Social, Humanities, and Education Studies (SHEs): Conference Series https://jurnal.uns.ac.id/shes
p-ISSN 2620-9284

e-ISSN 2620-9292 


\section{PENDAHULUAN}

IImu pengetahuan alam merupakan ilmu pengetahuan yang berkaitan dengan lingkungan hidup. Manusia dan lingkungan saling terkait. Sikap manusia terhadap lingkungan berpengaruh. Lingkungan akan tetap lestari apabila manusia menggunakan kecerdasannya untuk menjaga lingkungan. Namun, lingkungan juga bisa rusak karena ketidakpedulian manusia terhadap lingkungan. Masalah tentang lingkungan bukan hanya menjadi sebuah isu saja, namun banyak terjadi kerusakan dan perubahan lingkungan yang terjadi saat ini. Misalnya, banyak terjadi bencana alam di negara Indonesia seperti banjir, longsor, kebakaran hutan akibat panasnya suhu dipermukaan bumi, perubahan cuaca secara ekstrim diberbagi belahan bumi.

Kutanegara (2014) menyatakan bahwa lingkungan hidup tidak hanya milik generasi sekarang, tetapi juga milik generasi penerus dimasa mendatang. Sebagai salah satu upaya untuk menjaga kelestarian lingkungan dimasa mendatang adalah perlu dilakukannya tindakan nyata berupa kampanye penyadaran tentang pentingnya menjaga lingkungan dan melakukan berbagai tindakan nyata dalam kehidupan seharihari. Sikap peduli lingkungan merupakan sikap dan tindakan yang selalu berupaya mencegah kerusakan pada lingkungan alam di sekitarnya dan mengembangkan upaya-upaya untuk memperbaiki kerusakan alam yang sudah terjadi. (Wibowo, 2012)

Sikap peduli lingkungan di SD Negeri 1 Mendak masih rendah. Hal tersebut dibuktikan dari hasil wawancara peneliti dengan guru kelas V SD Negeri 1 Mendak, Delanggu, Klaten yang dilaksanakan pada tanggal 12 Januari 2018. Hasil wawancara tersebut didukung dengan hasil observasi yang dilaksanakan pada tanggal 15 Januari 2018. Sebagian besar siswa masih sering membuang sampah sembarangan, seperti membuang sampah di dalam laci meja, siswa masih sering menghindari jadwal piket yang sudah ditentukan.

Kepedulian lingkungan sekolah yang masih rendah disebabkan karena masih sedikitnya upaya menumbuhkan kesadaran tentang hidup bersih dan sehat terhadap siswa, sehingga siswa kurang peduli terhadap lingkungan sekitar dan kurang mengetahui cara merawat dan menjaga lingkungan sekolah. Selain itu, penyebab rendahnya sikap peduli lingkungan dikarenakan cara mengajar yang diterapkan oleh guru masih sangat terbatas pada metode konvensional seperti ceramah. Hal tersebut membuat siswa menjadi kesulitan dalam memahami pentingnya menjaga lingkungan sekolah. Penyebab lain yang menjadi faktor rendahnya sikap peduli lingkungan siswa kelas V SD Negeri 1 Mendak yaitu kurang tegasnya sanksi yang di berikan kepada siswa yang tidak menjaga lingkungan sekolah.

Hasil observasi di kelas V SD Negeri 1 Mendak, rendahnya sikap peduli terhadap lingkungan juga tampak dari hasil angket yang di bagikan pada siswa kelas $\mathrm{V}$ SD Negeri 1 Mendak serta hasil pengamatan yang dilakukan oleh peneliti. Hasil pengamatan sikap peduli lingkungan yang dilakukan di SD Negeri 1 Mendak belum nampak. Hal ini terlihat dari masih banyak siswa yang membuang sampah sembarangan seperti membuang rautan pensil dan plastik makanan di dalam laci, selain itu masih banyak pula siswa yang memetik tanaman di lingkungan sekolah untuk bermain. Kriteria sikap peduli lingkungan dikatakan sudah membudaya apabila skor yang didapat adalah $\geq 113$, sedangkan hasil yang diperoleh dari angket sikap peduli lingkungan ditemukan 8 siswa yang mendapatkan skor dibawah 113 atau 44,4\% siswa yang mendapat skor antara 76-113 dikategorikan sikap peduli lingkungan sedikit muncul dan terdapat 10 siswa yang memperoleh skor dibawah 75 atau 55,6\% siswa yang mendapat skor dibawah 75 dikategorikan sikap peduli lingkungan sedikit muncul, dan belum terdapat satupun siswa yang mendapatkan skor diatas 113 atau dalam kategori membudaya. Hasil angket menunjukkan bahwa skor terendah adalah 62 dan skor tertinggi adalah 92. Dari hasil angket dan pengamatan pada saat pratindakan, dapat disimpulkan bahwa belum terdapat satupun siswa yang memenuhi kriteria dari sikap peduli terhadap lingkungan. Dengan demikian dapat dikatakan bahwa sikap 
peduli lingkungan yang mulai muncul hanya terdapat 4 siswa dari 18 siswa atau $22 \%$ siswa, dan tidak ada siswa yang memiliki kategori sikap peduli lingkungan yang membudaya.

Untuk mengatasi rendahnya sikap peduli lingkungan siswa kelas V SD Negeri 1 Mendak, maka peneliti menerapkan pembelajaran Science, Environment, Technology, and Society (SETS) sebagai salah satu alternatif untuk menciptakan pembelajaran yang membangkitkan keaktifan dan partisipasi siswa. model pembelajaran SETS merupakan suatu strategi pembelajaran yang memadukan pemahaman dan pemanfaatan sains, teknologi dan masyarakat, dengan tujuan agar konsep sains dapat diaplikasikan melalui ketrampilan yang bermanfaat bagi siswa dan masyarakat.(Rizema,2013)

Model pembelajaran SETS berkaitan erat dengan lingkungan. Model pembelajaran ini dilakukan dengan mengambil permasalahan yang ada di lingkungan sekitar. Seperti dalam jurnal Rosario (2009) : "The models SETS the goal of STS not only to decision making but more tu action, hence it is important to know what student feel they can do while taking and after the environmental science course". Hal ini berarti bahwa model pembelajaran SETS tidak hanya untuk pengambilan keputusan tetapi lebih ke tindakan, maka penting untuk mengetahui apa yang dirasakan oleh siswa pada saat berada di lingkungan.

Melalui model pembelajaran Science, Environment, Technology, and Society (SETS) dapat menjadikan suasana belajar lebih aktif. Yoruc (2010) dalam jurnalnya yang berjudul The Effect Of Science Technology and Society (SETS) Interaction on Teaching Chemistry menyatakan bahwa "The aim of the SETS related courses aim to anable individual to understand science better, to encourage student with creativity and critical thinking, and to make boring and abstract topic more interesting and fun". Hal tersebut berarti bahwa model pembelajaran SETS bertujuan untuk memungkinkan individu untuk memahami sains lebih baik, dan mendorong untuk lebih kreatif dan berpikir kritis, serta membuat topik yang membosankan dan abstrak menjadi lebih menarik dan menyenangkan Siswa mampu mengidentifikasi permasalahan berkaitan dengan menjaga kebersihan lingkungan yang ada disekolah untuk dibawa ke dalam kelas sebagai objek belajar, siswa diajak berdiskusi dan memberikan siswa untuk menghubungkan sains, lingkungan, teknologi, dan masyarakat. Dengan demikian siswa dapat memahami tentang pentingnya menjaga kebersihan lingkungan dan dapat menerapkan sikap peduli lingkungan di masyarakat.

Berdasarkan uraian tersebut, rumusan masalah dalam penelitian ini yaitu bagaimana penerapan model pembelajaran SETS untuk meningkatkan sikap peduli lingkungan pada pembelajaran IPA siswa kelas V SDN 1 Mendak tahun ajaran 2017/2018?

Tujuan penelitian ini adalah meningkatkan sikap peduli lingkungan pada pembelajaran IPA dengan menerapkan model pembelajaran SETS pada siswa kelas V SDN 1 Mendak tahun ajaran 2017/2018.

\section{METODE}

Penelitian ini dilaksanakan pada siswa kelas V SD Negeri 1 Mendak tahun pelajaran 2017/2018. Waktu penelitian selama kurang lebih enam bulan yakni dari bulan Desember 2016 sampai dengan Mei 2017. Data yang dikumpulkan dalam penelitian ini berupa angket, hasil wawancara dengan guru dan siswa, hasil observasi, serta foto maupun video proses pembelajaran. Sumber data yang digunakan dalam penelitian ini adalah siswa dan guru. Siswa adalah sumber untuk memperoleh data tentang sikap peduli lingkungan . guru adalah sumber untuk memperoleh data tentang hasil wawancara sebelum dan sesudah menggunakan model pembelajaran SETS, selain itu untuk memperoleh nilai kinerja guru dalam pembelajaran yang dilaksanakan. Teknik pengumpulan data yang digunakan yaitu observasi, wawancara, angket, dan 
dokumentasi. Validitas data yang digunakan yaitu validitas isi, triangulasi sumber dan teknik. Data yang diperoleh dalam penelitian ini dianalisis menggunakan model interaktif Milles dan Huberman.Penelitian ini menggunakan prosedur penelitian yang dilakukan melalui 2 siklus. Setiap siklus terdiri dari empat tahap yaitu perencanaan, tindakan, observasi dan refleksi.

\section{HASIL DAN PEMBAHASAN}

Berdasarkan hasil skor pengamatan sikap peduli lingkungan pada kondisi awal sebelum diterapkannya model pembelajaran SETS maka dapat dibuat distribusi skor sikap peduli lingkungan kelas $\mathrm{V}$ pada kondisi awal dapat dilihat pada tabel dan gambar berikut:

Tabel 1. Distribusi Skor Pengamatan Sikap Peduli Lingkungan kelas V SD Negeri 1 Mendak pada kondisi Awal

\begin{tabular}{|c|c|c|c|c|c|}
\hline No & Interval & $\begin{array}{l}\text { Frekuensi } \\
\text { (fi) }\end{array}$ & $\begin{array}{c}\text { Nilai tengah } \\
\text { (xi) }\end{array}$ & fi.xi & $\begin{array}{c}\text { Presentase } \\
(\%)\end{array}$ \\
\hline 1. & $54-60$ & 5 & 57 & 285 & $27,8 \%$ \\
\hline 2. & $61-67$ & 3 & 64 & 192 & $16,7 \%$ \\
\hline 3. & 68-74 & 1 & 71 & 71 & $5,6 \%$ \\
\hline 4. & $75-81$ & 6 & 78 & 468 & $33,3 \%$ \\
\hline 5. & $82-88$ & 1 & 85 & 85 & $5,6 \%$ \\
\hline 6. & $89-95$ & 2 & 92 & 184 & $11,1 \%$ \\
\hline jumlah & & 18 & & & \\
\hline \multicolumn{6}{|c|}{ Skor rata-rata 70,83} \\
\hline \multicolumn{6}{|c|}{ Ketuntasan klasikal 0\% } \\
\hline \multicolumn{6}{|c|}{ Nilai tetinggi 94} \\
\hline \multicolumn{6}{|c|}{ Nilai terendah 54} \\
\hline
\end{tabular}

Berdasarkan data di atas, sebagian besar siswa belum mencapai kriteria ketuntasan minimal yang telah ditetapkan yaitu 113. Dari 18 siswa, belum terdapat siswa yang memiliki kategori sikap peduli lingkungan membudaya, 61,1\% siswa kategori sikap peduli lingkungan sedikit muncul dan 38,9\% siswa memiliki kategori sikap peduli lingkungan mulai muncul. Setelah digunakan model pembelajaran Science Environment Technology and Society (SETS) dalam pembelajaran IPA pada siklus I pertemuan 1 menunjukkan peningkatan. Hasil selengkapnya pengamatan sikap peduli lingkungan siklus I pertemuan 1 dapat dilihat pada Tabel 2 sebagai berikut:

Tabel 2. Distribusi Skor Pengamatan Sikap Peduli Lingkungan kelas V SD Negeri 1 Mendak siklus I pertemuan ke-1

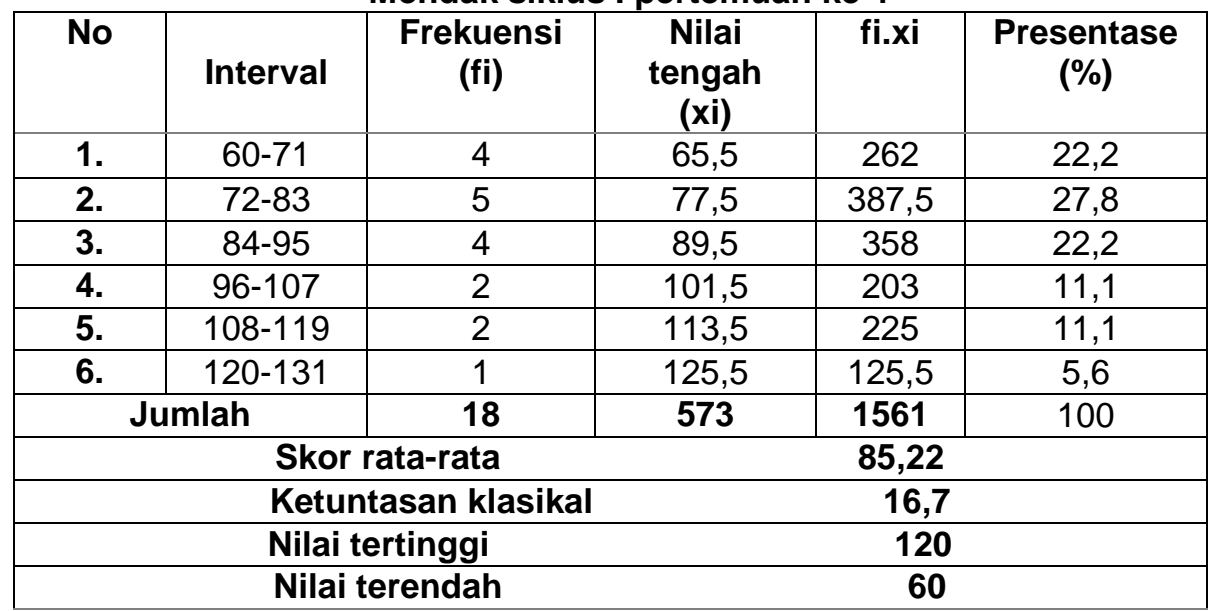


Pada siklus I pertemuan 1 ada 3 siswa yang memiliki kategori membudaya atau $16,7 \%, 8$ siswa memiliki kategori mulai muncul atau 44,4\%, dan 7 siswa yang memiliki kategori sedikit muncul atau 38,9\%. Nilai terendah 60, nilai tertinggi 120 dan rata-rata nilai 85,22 . Berdasarkan data tersebut dapat diketahui bahwa siswa yang memiliki kategori membudaya terdapat $16,7 \%$ sehingga target pada indikator kinerja belum tercapai, maka penelitian dilanjutkan pada siklus I pertemuan 2.

Pada siklus I pertemuan 2 sikap peduli lingkungan menunjukkan adanya peningkatan. Hasil selengkapnya dapat dilihat pada Tabel 3 sebagai berikut:

Tabel 3. Distribusi Skor Pengamatan Sikap Peduli Lingkungan kelas V SD Negeri 1 Mendak siklus I pertemuan ke-2

\begin{tabular}{|c|c|c|c|c|c|}
\hline No & Interval & $\begin{array}{c}\text { Frekuensi } \\
\text { (fi) }\end{array}$ & $\begin{array}{c}\text { Nilai } \\
\text { tengah } \\
\text { (xi) }\end{array}$ & fi.xi & $\begin{array}{c}\text { Presentase } \\
(\%)\end{array}$ \\
\hline $\mathbf{1 .}$ & $63-74$ & 3 & 68,5 & 205,5 & 16,7 \\
\hline $\mathbf{2 .}$ & $75-86$ & 1 & 80,5 & 80,5 & 5,6 \\
\hline $\mathbf{3 .}$ & $87-98$ & 4 & 92,5 & 370 & 22,2 \\
\hline $\mathbf{4 .}$ & $99-110$ & 2 & 104,5 & 209 & 11,1 \\
\hline $\mathbf{5 .}$ & $111-122$ & 7 & 116,5 & 815,5 & 38,9 \\
\hline $\mathbf{6 .}$ & $123-134$ & 1 & 128,5 & 128,5 & 5,6 \\
\hline jumlah & \multicolumn{6}{|c|}{ Skor rata-rata } & 591 & 1809 & 100 \\
\hline \multicolumn{6}{|c|}{$\mathbf{9 3 , 5}$} \\
\hline Ketuntasan klasikal & $\mathbf{3 8 , 9} \%$ \\
\hline Nilai tertinggi & $\mathbf{1 2 3}$ \\
\hline & Nilai terendah & $\mathbf{6 3}$ \\
\hline
\end{tabular}

Pada siklus I pertemuan 2 ada 7 siswa yang memiliki kategori membudaya atau $38,9 \%$, 8 siswa memiliki kategori mulai muncul atau $44,4 \%$, dan 3 siswa yang memiliki kategori sedikit muncul atau 16,7\%. Nilai terendah 63, nilai tertinggi 123 dan rata-rata nilai 93,5. Berdasarkan data tersebut dapat diketahui bahwa siswa yang memiliki kategori membudaya terdapat $38,9 \%$ sehingga target pada indikator kinerja belum tercapai, maka penelitian dilanjutkan pada siklus I pertemuan 2. Pada siklus II pertemuan 2 sikap peduli lingkungan menunjukkan adanya peningkatan. Hasil selengkapnya dapat dilihat pada Tabel 4 sebagai berikut:

Tabel 4. Distribusi Skor pengamatan Sikap Peduli Lingkungan siklus II pertemuan 1

\begin{tabular}{|c|c|c|c|c|c|}
\hline No & Interval & $\begin{array}{l}\text { Frekuensi } \\
\text { (fi) }\end{array}$ & $\begin{array}{c}\text { Nilai } \\
\text { tengah } \\
\text { (xi) }\end{array}$ & fi.xi & $\begin{array}{c}\text { Presentase } \\
\text { (\%) }\end{array}$ \\
\hline 1. & $69-82$ & 3 & 75,5 & 205,5 & 16,7 \\
\hline 2. & $83-96$ & 0 & 89,5 & 80,5 & 0 \\
\hline 3. & $97-110$ & 4 & 103,5 & 370 & 22,2 \\
\hline 4. & $111-124$ & 6 & 117,5 & 209 & 33,3 \\
\hline 5. & $125-138$ & 5 & 131,5 & 815,5 & 27,8 \\
\hline jumlah & & 18 & 517,5 & 1809 & 100 \\
\hline \multicolumn{6}{|c|}{ Skor rata-rata } \\
\hline \multicolumn{4}{|c|}{ Ketuntasan klasikal } & \multicolumn{2}{|c|}{$51,1 \%$} \\
\hline \multicolumn{4}{|c|}{ Nilai tertinggi } & \multicolumn{2}{|c|}{138} \\
\hline \multicolumn{4}{|c|}{ Nilai terendah } & \multicolumn{2}{|c|}{69} \\
\hline
\end{tabular}


Pada siklus II pertemuan 1 ada 11 siswa yang memiliki kategori membudaya atau $61,1 \%$, 4 siswa memiliki kategori mulai muncul atau 22,2\%, dan 3 siswa yang memiliki kategori sedikit muncul atau 16,7\%. Nilai terendah 69, nilai tertinggi 138 dan rata-rata nilai 109,3. Berdasarkan data tersebut dapat diketahui bahwa siswa yang memiliki kategori membudaya terdapat $61,1 \%$ sehingga target pada indikator kinerja belum tercapai, maka penelitian dilanjutkan pada siklus II pertemuan 1.

Pada siklus II pertemuan 2 sikap peduli lingkungan menunjukkan adanya peningkatan. Hasil selengkapnya dapat dilihat pada Tabel 5 sebagai berikut:

Tabel 5. Distribusi Skor Pengamatan Sikap Peduli Lingkungan kelas V SD Negeri 1 Mendak siklus II pertemuan ke-2

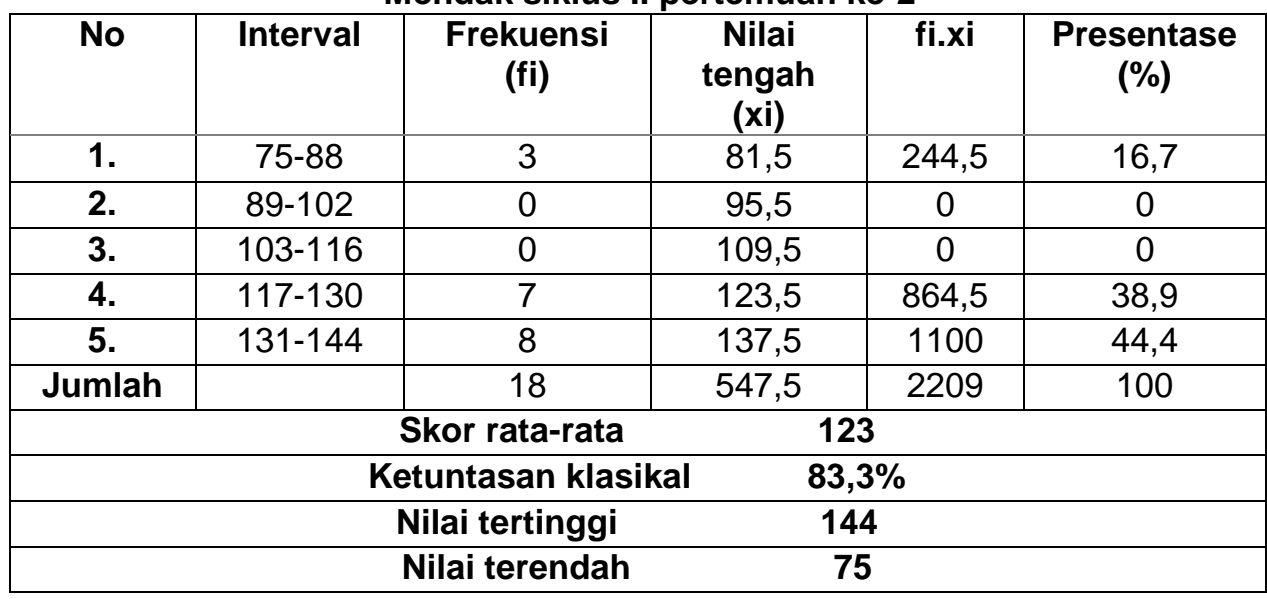

Pada siklus II pertemuan 2 ada 15 siswa yang memiliki kategori membudaya atau $83,3 \%, 2$ siswa memiliki kategori mulai muncul atau 11,1\%, dan 1 siswa yang memiliki kategori sedikit muncul atau 5,6\%. Nilai terendah 75, nilai tertinggi 144 dan rata-rata nilai 123 . Berdasarkan data tersebut dapat diketahui bahwa siswa yang memiliki kategori membudaya terdapat $83,3 \%$ sehingga target pada indikator kinerja sudah tercapai, maka penelitian diakhiri pada siklus II pertemuan 2.

Hasil nilai pemahaman sikap peduli lingkungan siklus II meningkat dan telah melebihi indikator kinerja yaitu $83,3 \%$ siswa mencapai batas KKM atau memiliki kategori sikap peduli lingkungan membudaya, oleh karena itu peneliti mengakhiri tindakan pengamatan sikap peduli lingkungan siswa kelas V SD Negeri 1 Mendak.

Peningkatan nilai sikap peduli lingkungan dapat dilihat pada saat kondisi awal sebelum diterapkannya model pembelajaran SETS menunjukkan bahwa ketuntasan klasikal sebesar $0 \%$ dan skor rata-rata kelasnya yaitu 70,83 . Terlihat pada siklus I pertemuan ke-1 mengalami peningkatan yaitu diperoleh ketuntasan klasikal sebesar $6,7 \%$ dan skor rata-rata kelas seesar 85,22. Dilanjutkan pada pertemuan ke-2, nilai sikap peduli lingkungan siswa kembali mengalami peningkatan yaitu ketuntasan klasikal diperoleh sebesar 38,9\% siswa dan rata-rata kelas sebesar93,5.

Penelelitian belum berhasil karena belum mencapai indikator yang telah ditetapkan, yaitu penelitian akan berhasil apabila terdapat 14 siswa dari 18 siswa yang mendapat skor diatas 113 atau memiliki sikap peduli lingkungan yang membudaya. Oleh karena itu, peneliti melanjutkan penelitian di siklus II, dengan memperbaiki metode, pembelajaran dan kinerja guru yang kurang pada siklus I. 
Pada siklus II pertemuan ke-1 terjadi peningkatan nilai sikap peduli lingkungan siswa yaitu ketuntasan klasikal diperoleh $61,1 \%$ siswa dan skor rata-rata kelas diperoleh 109,3. Dilanjutkan pada pertemuan ke-2, sikap peduli lingkungan siswa meningkat lagi yaitu ketuntasan klasikal diperoleh sebesar $83,3 \%$ siswa dan skor ratarata kelas diperoleh 123. Pada siklus II, peneliti sudah mencapai indikator kinerja yang telah ditetapkan yaitu sudah melebihi dari $80 \%$ siswa yang memiliki sikap peduli lingkungan membudaya. Oleh karena itu, penelitian berakhir di siklus II.

Meningkatnya sikap peduli lingkungan melalui model pembelajaran SETS sesuai dengan teori yang dikemukakan oleh Hardini (2012) yaitu model pembelajaran SETS merupakan model pembelajaran yang berkaitan dengan lingkungan sehingga dapat meningkatkan kepedulian terhadap lingkungan sekitar.

Penerapan model pembelajaran SETS didukung penelitian yang dilakukan oleh Fitrianita Utami yaitu untuk meningkatkan pemahaman konsep pengaruh perubahan lingkungan fisik terhadap dataran.

\section{SIMPULAN}

Berdasarkan hasil penelitian tindakan kelas yang telah dilaksanakan selama dua siklus dapat disimpulkan bahwa model pembelajaran Science Environment Technology and Society (SETS) dapat meningkatkan sikap peduli lingkungan pada siswa kelas $\mathrm{V}$ SD Negeri 1 Mendak tahun pelajaran 2017/2018.

Implikasi dari penelitian ini yaitu digunakan sebagai petunjuk bagi guru mengenai penerapan model pembelajaran SETS untuk meningkatkan sikap peduli terhadap lingkungan.

\section{DAFTAR PUSTAKA}

Hardini. (2012). Model Pembelajaran Inovatif dan Kreatif. Yogyakarta: Pustaka Pelajar. Kutanegara, P.M. (2014). Membangun Masyarakat Indonesia Peduli Lingkungan.Yogyakarta: Gajah Mada University Press.

Rizema, S. (2013). Desain Belajar Mengajar Kreatif berbasis Sains . Yogyakarta: Diva Press.

Rosario,B.I.(2009). Science Technology Society and Environment (STSE) Approach in Environmental Science for Nonscience Student in a Local Cultur. Liceo Journal of Higher Education Research, 6 (1), 2094-1064.

Wibowo, A. (2013). Menejemen Pendidikan Karakter di Sekolah. Yogyakarta: Pustaka Pelajar.

Yoruc, N. (2010). The Effect of Science Technology Society Environment (STSE) Interactions on Teaching Chemistry. Natural Science, 2 (12), 1417-1424. 